\title{
The Effect of Consumption Value, Attitude Toward Local Food and Food Destination Image towards Repurchase Intention on The Culinary Tourism of Bakso Bakar Trowulan Malang According to Tourists from Surabaya City
}

\author{
Galuh Fandy Asmoro ${ }^{\mathrm{a}}$, Oliandes Sondakh ${ }^{\mathrm{b}}$, Amelia $^{\mathrm{c} *}$ \\ a galuhfandy15@gmail.com \\ ${ }^{a}$ Master of Management Student at Pelita Harapan University, Surabaya 60234, Indonesia \\ ${ }^{b, c}$ The Lecturer of Master of Management at Pelita Harapan University, Surabaya 60234, Indonesia
}

\begin{abstract}
The need for travel will continue to increase in line with the need for refreshment as a result of an increase in work activity. One type of tourism is culinary tourism which is developing very positively. The culinary world is closely related to the region or place, identity and culture. Almost all regions in Indonesia have a variety of local foods such as regional specialties. As well as culinary tourism in Malang which is very popular among tourists. One of the popular culinary destinations for Malang food is Bakso Bakar Trowulan. This restaurant is one of the pioneering menus of a grilled meatball which is a typical Malang food. The purpose of this study is to determine the effect of Quality, Health, Price, Emotional, Prestige, Interaction, Epistemic, Attitude Toward Local Food, Food Destination Image on Repurchase Intention on the culinary tourism of Bakso Bakar Trowulan in Malang Raya according to tourists from Surabaya Raya. This study is causal, the method used is quantitative methods of processing the data using SPSS. Data was collected by distributing questionnaires to 101 respondents, with the characteristics of male and female respondents aged 18-60 years. The respondent is domiciled in Surabaya Raya, namely the City of Surabaya, Sidoarjo Regency \& Gresik Regency, the respondent has visited Bakso Bakar Trowulan at least once in the last 1 year and the respondent visits Bakso Bakar Trowulan not alone, but with family or friends. The results showed that the Attitude Toward Local Food to Food Destination Image shows a significant positive result with a regression coefficient of 0.769; Food Destination Image to Repurchase Intention shows significant positive results with a regression coefficient of 0.766; Emotional to Attitude Toward Local Food shows a significant positive result with a regression coefficient of 0.310; Prestige against Attitude Toward Local Food shows a significant positive result with a regression coefficient of 0.228; Quality towards Attitude Toward Local Food showed a significant positive result with a regression coefficient of 0.218; Price to Attitude Toward Local Food shows a significant positive result with a regression coefficient of 0.183 .
\end{abstract}

Keywords: Consumption Value, Attitude Toward Local Food, Food Destination Image, Repurchase Intention, Culinary Tourism

\section{Main text}

Along with the increasing population in the world, the need for traveling is currently increasing, refreshing is considered as one of the solutions to the increasingly busy work (Soebagyo, 2012). According to article 14 of the Tourism Law Number 10 of 2009 , one part of tourism is food \& beverage services, the type of business includes restaurants, teahouses, cafes, and food sales centers. The development of culinary tourism is very active, the culinary world is closely related to regions or places, identity and culture 
(www.lifestyle.okezone.com, downloaded on May 29, 2020). The development of culinary tourism has an impact on a very rapid economic increase, almost all regions in Indonesia have a variety of local foods such as regional specialties and traditional foods. Like in Malang, Malang is a tourist destination in Indonesia, especially as a major tourist destination in East Java because it has advantages in natural tourism, artificial tourism, and culinary tourism. Culinary tourism is becoming increasingly popular among tourists, various information platforms such as television, blogs, vlogs and social media have participated in creating content about culinary tourism in Malang City. This is certainly a very profitable opportunity for Malang City to attract tourists to come and have a culinary tour in Malang City, and to become part of the development of culinary tourism in Indonesia.

According to Prayogo \& Suryawan (2018) culinary tourism makes the economy in the city of Malang increase and tourists can learn about culture. The types of culinary tourism that are a favorite of tourists in Malang include, restaurants, cafes and food sales centers. One type of food that is very popular in Malang is grilled meatballs. Grilled meatballs menu is a type of food made from flour and meat that is shaped into a round and cooked then grilled with charcoal, has a tasty and chewy taste and is eaten with soup. According to Syoalehat et al. (2016) Malang is very famous for its meatball menu which has succeeded in becoming a typical Malang dish. One type of meatball that has become iconic is the grilled meatball, the grilled meatball has become a meatball icon that is very popular with the people of Malang and even tourists from outside Malang. There is a grilled meatball restaurant which is the most popular among tourists which has an image of the taste of grilled meatballs as a typical food in Malang, namely Bakso Bakar Trowulan which was founded in 1999 at Trowulan Temple Streat No. 56, Malang City. This restaurant sells grilled meatballs as the only main menu and is a pioneer of grilled meatballs as a typical food in Malang.

For people living in Surabaya City, this type of meatball food must have been consumed daily because it is very often found and easy to find around the neighborhood. The ease of reaching this type of meatball food has an impact on the difficulty of getting the appeal of the desire to consume meatballs for culinary tourism purposes in the context of refreshing in the city, especially the meatball menu in Greater Surabaya is served like the meatball menu in general in Indonesia, namely boiled meatballs. So that with the variety of unique culinary delights offered in Malang, especially popularity, and the image of Malang grilled meatballs that are served grilled with various spices, it will be a special attraction for tourists from Surabaya City to come for a culinary tour to Malang City. Compared to Surabaya City, Malang City provides its own sensation, where its location in the highlands provides cooler and fresher air, so it will give the impression of pleasure, comfort and even relaxation for tourists while traveling or in restaurants, restaurants, cafes, or a food sales center. According to Prayogo \& Suryawan (2018), culinary tourism in Malang City has diversity in terms of choice, taste, and quality which makes culinary tourists more interested in culinary tours. In addition, some Malang specialties display their unique food enjoyment in the form of classic elements that are still preserved today.

This Research will take a Bakso Bakar Trowulan as an object. Bakso Bakar Trowulan is the most favorite restaurant visited by tourists for a culinary tour in Malang. This restaurant has a very good image on culinary tourism in Indonesia and attracts many tourists from outside the city to come and eat. This research can be used as a reference for Bakso Bakar Trowulan to find new possible approaches in increasing the value of consumption by tourists on culinary tourism. In addition, the research results can be a reference for the Malang government to strengthen Malang's positioning as a culinary tourism destination with checked the effect of the local food consumption value by food tourists from Surabaya City regarding Attitudes Toward Local Food, food destination images, and repurchase intentions. 


\section{Litterature Review}

\subsection{Theories and Hypotheses \\ 2.1.1 Consumption Value}

Consumers choose products and brands based on these five consumer value theories. The purpose of this theory is to explain and describe consumption patterns and behavior. Consumer value theory states that consumer choice behavior is influenced by several consumer values, namely functional, emotional, social, epistemic, and conditional. Each consumption value has a different contribution depending on different contexts (Sheth et al. 1991). Consumption value refers to the utility that is felt or obtained by consuming a product. The concept of consumption value has been applied to food consumption in tourism.

\subsubsection{Quality}

Quality is the utility obtained by consuming local food at the destination based on the quality and performance expected of local food. This quality is the extent to which a characteristic is closely related to meeting requirements. The combination of attributes and characteristics can determine the extent to which the results obtained can answer customer needs. Quality is defined as anything that can meet / satisfy customer needs (Choe \& Kim, 2018; Sunyoto \& Susanti. 2015; Ariani, 2014). Therefore, we predict the Quality has a significant effect on Attitude Toward Local Food. This leads to the hypotheses as the following:

H1: Quality has a significant effect on Attitude Toward Local Food.

\subsubsection{Health}

Health is the utility that is obtained by consuming local food for a purpose based on the ability of local food to improve health. Health standards contained in food are foods that must contain various kinds of nutrients needed by the body. Healthy foods contain rich nutrients, such as carbohydrates, protein, minerals, vitamins and some balanced unsaturated fats, or simply 4 healthy menus 5 perfect. Healthy food is a nutritious food that contains macronutrients (carbohydrates, protein and healthy fats) and micronutrients (vitamins and minerals) (Choe \& Kim, 2018; Salsabilla, 2017; Oetoro et al. 2013). Therefore, we predict the Health has a significant effect on Attitude Toward Local Food. This leads to the hypotheses as the following:

H2: Health has a significant effect on Attitude Toward Local Food.

\subsubsection{Price}

Price is the amount of money charged for a product or service, or the amount of value that customers exchange for the benefits of owning or using the product or service. Price is a measure of public satisfaction with the product purchased. Price is an exchange rate that can be equated with money or other goods at a certain time and place from a person or group of people for a good or service (Kotler \& Amstrong, 2014; Gitosudarmo (2014); Sudaryono, 2016). Therefore, we predict the Price has a significant effect on Attitude Toward Local Food. This leads to the hypotheses as the following:

H3: Price has a significant effect on Attitude Toward Local Food.

\subsubsection{Emotional}

Emotional is the utility that is obtained by consuming local food with an aim based on the ability of local food to stimulate the desired feelings. Emotion comes from the word emotional, in other words something will drop something. For example, because emotions have an element of joy, they encourage the individual to change their emotions and cause laughter. Or vice versa, anger shows the mood to attack or destroy something 
to make someone angry. Emotion refers to any thought, feeling, desire, activity or upheaval from a mental state that is great or extraordinary (Choe \& Kim, 2018; Romlah, 2010; Riyanto, 2014). Therefore, we predict the Emotional has a significant effect on Attitude Toward Local Food. This leads to the hypotheses as the following:

H4: Emotional has a significant effect on Attitude Toward Local Food.

\subsubsection{Prestige}

Prestige is a condition in which someone has their own pride after consuming certain goods or services. Prestige is a practical tool that can be obtained by consuming local food based on local food capabilities to improve social self-concept. Prestige is a personal value that must be obtained through consumer products that illustrates the concept of personal reputation (sometimes called status). Prestige motivation is determined by five sources of value: attractive, unique, social, emotional, and quality. After one or more of these sources of value is seen from the product or service attributes, it is considered to have a well-known value (Wibowo \& Riyadi, 2017; Choe \& Kim, 2018; Jones \& Moital, 2017). Therefore, we predict the Prestige has a significant effect on Attitude Toward Local Food. This leads to the hypotheses as the following:

H5: Prestige has a significant effect on Attitude Toward Local Food.

\subsubsection{Interaction}

Interaction is the utility that is obtained by consuming local food at a destination based on the ability of local food to increase interaction between people. Interaction is a behavio that occurs when two or more objects influence each other. The concept of two-way influence is important in the concept of interaction, not a oneway causality. Interaction is a relationship between two systems, this relationship occurs in such a way that an event in one system will affect an event in another system. Interaction is a social relationship between individuals, and related individuals will influence each other (Choe \& Kim, 2018; Susanto, 2013; Chaplin, 2011). Therefore, we predict the Interaction has a significant effect on Attitude Toward Local Food. This leads to the hypotheses as the following:

H6: Interaction has a significant effect on Attitude Toward Local Food.

\subsubsection{Epistemic}

Epistemic is epistemic value which refers to the perceived utility obtained by consuming local food at the destination based on the ability of local food to arouse curiosity, update information, and satisfy one's desire for knowledge. Epistemic is the advantage of getting the information expected from the prediction results. Epistemic is a type of value possessed by knowledge, and there may be other epistemic items such as defense and understanding (Choe \& Kim, 2018; Friston et al. 2015; Greco \& De, 2018). Therefore, we predict the Epistemic has a significant effect on Attitude Toward Local Food. This leads to the hypotheses as the following:

H7: Epistemic has a significant effect on Attitude Toward Local Food.

\subsubsection{Attitude Toward Local Food}

Attitude Toward Local Food refers to the psychological tendencies expressed by summarized evaluations of local food by tourists with the level of likes or dislikes. According to, attitude is a reaction that arises from seeing, feeling, and understanding something. This attitude can cause objects to appear uniform, or attitudes tend to be consistent with behavior consumer attitudes as a person's overall assessment of a concept, and this assumption is more positive. Assessment). When someone buys a brand, there is a higher probability that 
someone will buy or use that brand (Choe \& Kim, 2018; Purwianti \& Tio 2017; Kotler \& Armstrong, 2014). Therefore, we predict the Attitude Toward Local Food has a significant effect on Food Destination Image. This leads to the hypotheses as the following:

H8: Attitude Toward Local Food has a significant effect on Food Destination Image.

\subsubsection{Food Destination Image}

Food Destination Image is a food destination image that refers to the subjective impression of tourists about the reality of food destinations. Destination Image is a belief, concept, and is also related to a person's impression of a place or destination. Destination image is a perception that is formed based on the collection of information that has been received by tourists. Each destination has an image such as beliefs, impressions, and opinions about the destination. Then various factors such as weather, natural scenery, safety, sanitation and sanitation, friendliness, etc. considered comprehensively from the image formed (Choe \& Kim, 2018; Artuger \& Cetinsoz, 2017; Destari, 2017). Therefore, we predict the Food Destination Image has a significant effect on Repurchase Intention. This leads to the hypotheses as the following:

H9: Food Destination Image has a significant effect on Repurchase Intention.

\subsubsection{Research Model}

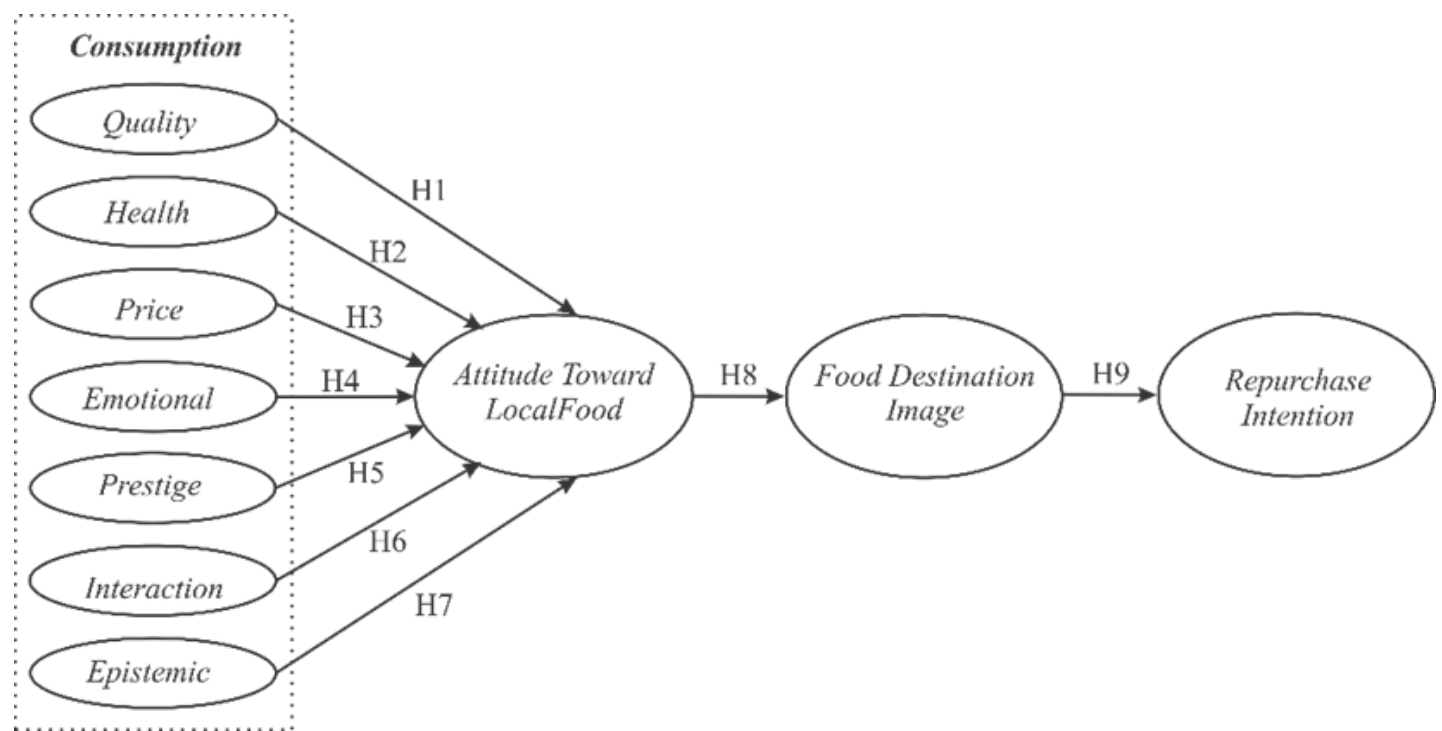

Figure 1: The Framework of Research Model

Based on previous study Choe \& Kim (2018) this study identified four main categories of variables, Consumption Value represented by Quality, Health, Price, Emotional, Prestige, Interaction and Epistemic, towards Attitude Toward Local Food, toward Food Destination Image and Repurchase Intention.

\section{Research Methods}

This research is causal research, because it is used to develop existing research models to test the research hypotheses that are determined based on literature review to answer the problems identified in the previous chapter. The research method used in this study is a quantitative method, where this method is a scientific 
approach to managerial and economic decision making. The method used in this study will refer to references that can carry out a simultaneous analysis process associated with a multi-variable research model, the Linier Regression. The program used is the SPSS 25 software program. This chapter describes the object of research directed at analyzing models about the influence of local food Consumption Value by food tourists from Surabaya regarding Attitudes Toward Local Food, Food Destination Images, and Repurchase Intentions on so Bakar Trowulan Restaurants. The population that will be used in this study is so Bakar Trowulan Restaurants Surabaya visitors. The sampling method used in this research is non-probability sampling. This study uses a questionnaire as the main tool in data collection. In this study, researchers will use a Snowball Sampling. Snowball Sampling is a technique for finding research subjects in which one subject gives the researcher the name of another subject, which in turn gives the third name, and so on. The area used as a place for distributing questionnaires was the Surabaya city, so that respondents were selected according to the criteria determined in this study. The characteristics of the respondents determined are men and women aged 18-60 years where the age is an early adulthood (Kotler and Armstrong, 2010), respondents have visited Bakso Bakar Trowulan Restaurants in the 1 year, and come with friends or family. The number of variables used in this study is 10 variables, therefore the minimum number of samples needed is 100 respondents, and for this study a total of 101 respondents will be determined. Data collection is done by distributing questionnaires to respondents in accordance with the characteristics of the sample that has been described previously. After completing the questionnaire, the respondent returns the questionnaire that has been filled out and will then be selected by the researcher. The selected questionnaire is a questionnaire that is completely filled out and according to the filling instructions. After selection, the selected questionnaire will be further processed. After the data is tabulated, then the research model will be tested using SPSS software version 25 . The questionnaire in this study will be divided into two parts. The first part contains questions to get general information about the respondent that is useful to determine the suitability of the characteristics of the respondent with the sample criteria. The second part contains several statements to obtain research data and analyze the influence of Consumption Value, Attitude Toward Local Food, Food Destination Image on Repurchase Intention. Bakso Bakar Trowulan Malang Restaurants. The scale used in this study is a Likert Scale, where the answer is provided at intervals from 1=Strongly Disagree (STS) to 5=Strongly Agree (SS). Statements are made using a scale of 1-5 to obtain internal data.

\section{Results and Discussion}

\subsection{Assessment of Measurement Model}

Table 1: Multiple Regression Effects of Quality, Health, Price, Emotional, Prestige, Interaction, Epistemic to Attitude toward Local Food

\begin{tabular}{|l|c|c|c|c|c|c|}
\hline \multicolumn{1}{|c|}{ Model/ Variable } & $\mathbf{R}$ & $\begin{array}{c}\text { Adj } \\
\mathbf{R}^{\mathbf{2}}\end{array}$ & $\mathbf{F}_{\text {sig }}$ & $\begin{array}{c}\text { Standardized } \\
\text { Coefficients Beta }\end{array}$ & $\mathbf{t}_{\text {sig }}$ & Hypotheses \\
\hline $\begin{array}{l}\text { Quality, Health, Price, } \\
\text { Emotional, Prestige, } \\
\text { Interaction, Epistemic } \\
\text { Attitude Toward Local Food }\end{array}$ & 0,737 & 0,509 & 0,000 & & & \\
\hline Quality & & & & & & \\
\hline Health & & & & 0,218 & 0,014 & Accepted \\
\hline Price & & & & 0,061 & 0,524 & Rejected \\
\hline Emotional & & & & 0,183 & 0,029 & Accepted \\
\hline Prestige & & & & 0,310 & 0,001 & Accepted \\
\hline Interaction & & & & 0,099 & 0,018 & Accepted \\
\hline Epistemic & & & & $-0,074$ & 0,264 & Rejected \\
\hline
\end{tabular}


Table 2: Simple Regression Effects of Attitude toward Local Food to Food Destination Image

\begin{tabular}{|c|c|c|c|c|c|c|}
\hline Model/ Variable & $\mathbf{R}$ & $\begin{array}{c}\text { Adj } \\
\mathbf{R}^{2}\end{array}$ & $\mathbf{F}_{\text {sig }}$ & $\begin{array}{c}\text { Standardized } \\
\text { Coefficients Beta }\end{array}$ & $\mathbf{t}_{\text {sig }}$ & Hypotheses \\
\hline $\begin{array}{l}\text { Attitude Toward Local Food } \\
* \text { Food Destination Image }\end{array}$ & 0,769 & 0,587 & 0,000 & & & \\
\hline Attitude Toward Local Food & & & & 0,769 & 0,000 & Accepted \\
\hline
\end{tabular}

Table 3: Simple Regression Effects of Food Destination Image to Repurchase Intention

\begin{tabular}{|l|c|c|c|c|c|c|}
\hline \multicolumn{1}{|c|}{ Model/ Variable } & $\mathbf{R}$ & $\begin{array}{c}\text { Adj } \\
\mathbf{R}^{\mathbf{2}}\end{array}$ & $\mathbf{F}_{\text {sig }}$ & $\begin{array}{c}\text { Standardized } \\
\text { Coefficients Beta }\end{array}$ & tsig & Hypotheses \\
\hline $\begin{array}{l}\text { Food Destination Image * } \\
\text { Repurchase Intention }\end{array}$ & 0,766 & 0,582 & 0,000 & & & \\
\hline Food Destination Image & & & & 0,766 & 0,000 & Accepted \\
\hline
\end{tabular}

Significancy value $\left(\mathbf{t}_{\text {sig }}\right)$ for each relationship between the variables tested are shown in table 1,2\&3. Causality relationships that occur between the Quality on Attitude Toward Local Food, Price on Attitude Toward Local Food, Emotional on Attitude Toward Local Food, Prestige on Attitude Toward Local Food, Attitude Toward Local Food on Food Destination Image, and Food Destination Image on Repurchase Intention has a significant relationship because $\mathbf{t}_{\text {sig }}$ values below 0,05 . As for the causality relationship that occurs between the Health on Attitude Toward Local Food, Interaction on Attitude Toward Local Food, Epistemic on Attitude Toward Local Food has insignificant relationship because the $\mathbf{t}_{\text {sig }}$ values above 0,05 .

\subsection{Hypotheses Testing}

Table 4: Summary of Testing Results.

\begin{tabular}{|l|l|}
\hline Hypotheses & Analysis \\
\hline H1: Quality has a significant effect on Attitude Toward Local Food. & Accepted \\
\hline H2: Health has a significant effect on Attitude Toward Local Food. & Rejected \\
\hline H3: Price has a significant effect on Attitude Toward Local Food. & Accepted \\
\hline H4: Emotional has a significant effect on Attitude Toward Local Food. & Accepted \\
\hline H5: Prestige has a significant effect on Attitude Toward Local Food. & Accepted \\
\hline H6: Interaction has a significant effect on Attitude Toward Local Food. & Rejected \\
\hline H7: Epistemic has a significant effect on Attitude Toward Local Food. & Rejected \\
\hline H8: Attitude Toward Local Food has a significant effect on Food Destination Image & Accepted \\
\hline H9: Food Destination Image has a significant effect on Repurchase Intention & Accepted \\
\hline
\end{tabular}




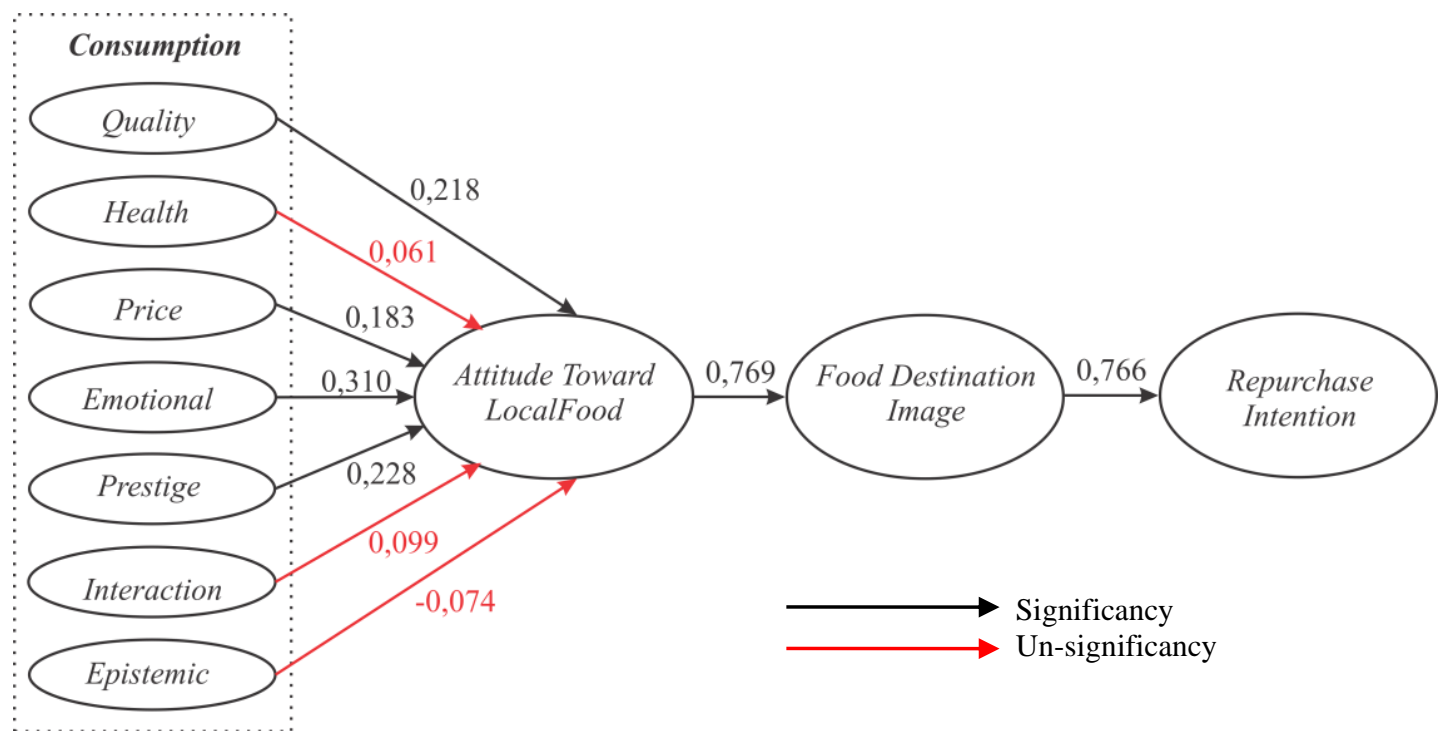

Fig. 2: The Framework of Analysis Result

\subsection{Discussion}

Based on SPSS 25 analysis result, estimation parameters between the Quality on Attitude Toward Local Food, Price on Attitude Toward Local Food, Emotional on Attitude Toward Local Food, Prestige on Attitude Toward Local Food, Attitude Toward Local Food on Food Destination Image, and Food Destination

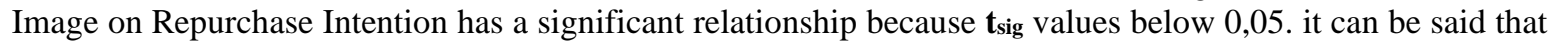
hypothesis $\mathrm{H} 1, \mathrm{H} 3, \mathrm{H} 4, \mathrm{H} 5, \mathrm{H} 8$ and $\mathrm{H} 9$ were accepted (This were showed at Table 1, Table 2, Table 3 and table 4). As for the estimation parameters between the Health on Attitude Toward Local Food, Interaction on Attitude Toward Local Food, Epistemic on Attitude Toward Local Food has insignificant relationship because the $\mathbf{t}_{\text {sig }}$ values above 0,05 . it can be said that hypothesis $\mathrm{H} 2, \mathrm{H} 6$ and $\mathrm{H} 7$ we are not accepted (This were showed at Table 1, Table 2, Table 3 and table 4). So, excluding Health, Interaction and Epistemic, the results exhibited that all the other hypothesized variables played important roles in predicting respondent's Attitude Toward Local Food, Food Destinations Image and Repurchase Intention at Bakso Bakar Trowulan Malang. The findings of this study provide several important implications for Attitude Toward Local Food, Food Destinations Image and Repurchase Intention especially in culinary in the future.

Emotional variable is the respondent's main concern and is the most important aspect to be addressed and developed immediately with the highest regression coefficient $=0,310$ and $\mathbf{t}_{\text {sig }}=0,001$ has a significant positive effect on Attitude Toward Local Food This indicator must be improved because consuming meatballs at Bakso Bakar Trowulan helps customers to be refreshed in order to overcome stress, entertain customers with a culinary tour in Malang City and make customers feel more relaxed because the air in Malang City is cooler than Surabaya City. Based on the general description, the respondents in this study were the millennial generation at the age of 22-27 and reaching the goal of Malang was for natural tourism, artificial tourism as well as culinary tourism. Millennial generation is known as an adventurous generation, from traveling they get fun and experience, not infrequently that makes tourism a lifestyle choice. (www.liputan6.com/lifestyle, downloaded January 27, 2021). According to Choe \& Kim (2018), emotional is the utility obtained by consuming local food with the aim of being based on the ability of local food to stimulate the desired feeling. Respondents who are tourists who come from outside Malang Raya, visit a place outside the city of course have goals such as finding ways to refresh and relieve stress in one way is a culinary tour at Bakso Bakar 
Trowulan, then respondents who are dominated by people. This millennial makes travel a lifestyle choice. This goal is of course in accordance with the concept of emotional which creates pleasant feelings. Represented by its indicators help with stress, can be comforting, and aid relaxation. These things are the most determining of the definition of emotional, which greatly affects Emotional being the greatest influence on attitudes towards local food.

The Prestige variable has a significant positive effect on Attitude Toward Local Food at Bakso Bakar Trowulan with a regression coefficient $=0,228$ and $\mathbf{t}_{\mathbf{s i g}}=0,018$. This show that Bakso Bakar Trowulan makes its customers feel prestigious, where customers feel that they are worthy to show photos / videos of this food to others and become an opportunity to show off their experience of eating this food to others so that it can impress others. Respondents in this study are tourists, so the main purpose of traveling, which is to help cope with stress, entertain yourself and relax, must be fulfilled first. Then the respondents in this study were the millennial generation at the age of 22-27 years who were active in using social media, after traveling there would have been a desire to capture the moment and show off on their social media. Millennials spend more of their traveling budget on tours or activities that can be remembered or shared with others (www.liputan6.com/lifestyle, downloaded on January 27, 2021. From this basis, respondents want to show off that they have also consumed them. Bakso Bakar Trowulan by sharing photos / videos of the experience of eating this food with others, which is why Prestige is the second biggest influence on Attitude toward Local Food.

The Quality variable has a significant positive effect on Attitude Toward Local Food at Bakso Bakar Trowulan with a regression coefficient $=0,218$ and $\mathbf{t}_{\text {sig }}=0,014$. This show that Bakso Bakar Trowulan has good quality ingredients, has an interesting variety of flavors, has a delicious taste and is interesting / unique to attract. Apart from consuming this food as a way of refreshing and for showing off, the quality factor of this food is also taken into consideration by the respondents. Moreover, the object in this study is food, so it remains an important consideration for someone to consume good quality food. Moreover, the uniqueness and deliciousness of the grilled meatball taste is the main attraction for many tourists visiting Bakso Bakar Trowulan. So that is why Quality is the third biggest influence on Attitude toward Local Food.

The Price variable has a significant positive effect on Attitude Toward Local Food at Bakso Bakar Trowulan with a regression coefficient $=0,183$ and $\mathbf{t}_{\text {sig }}=0,029$. This show that Bakso Bakar Trowulan has a reasonable price like other similar grilled meatballs, the price is affordable and reasonable. With food prices that are affordable, reasonable and reasonable as with similar grilled meatballs, it also determines the respondent's decision to consume Bakso Bakar Trowulan. Respondents in this study were mostly dominated by the millennial generation who were still students and fresh graduates who still had an income / income level of $<$ Rp. $3,800,000$ of $31.7 \%$. Where the income level tends to be middle to lower. When viewed from the research indicators, the price of Trwoulan Bakso Bakar tends to be affordable because all indicators are at the agreed level of agreement. However, price is not perceived as the main thing, but the umpteenth, this is because when a customer comes far from Surabaya for a tourist destination, of course they come with a budget that will be adjusted accordingly. Besides that, the main purpose of traveling for millennials, is an activity that provides a new experience, not a new item, they travel for an experience, not for an item (www.liputan6.com, downloaded on January 27, 2021. So, it's no wonder that Millennial generations spend more of their travel budget on tours or activities that can be remembered or told to others, they will actually set aside a little vacation budget to buy goods or food. Therefore, Price is perceived as not as important as others after Emotional, Prestige, Quality, which is why Price is the fourth largest influence on Attitude toward Local Food. 
The Interaction variable is a variable that has positive correlation but does not significantly influence Attitude Toward Local Food at Bakso Bakar Trowulan with a regression coefficient $=0,099$ and $\mathbf{t}_{\text {sig }}=0,264$. Even though the interaction variable was well perceived by the respondents, it had no significant effect on Attitude toward Local Food. This is because the interaction process that occurs between respondents and traveling companions in consuming Trowulan Bakso Bakso can also be obtained from eating food in other places. This result could be due to the interaction made by customers when they come to eat Bakso Bakar Trowulan with friends / family feels the same as when customers eat food elsewhere. Either consuming it at Bakso Bakar Trowulan or elsewhere, customers can still have good interactions with their traveling companions. Therefore, this factor is not a significant factor in influencing the respondent's decision to Attitude toward Local Food on Trowulan Baked Bakso.

The Health variable is a variable that has positive correlation but does not significantly influence Attitude Toward Local Food at Bakso Bakar Trowulan with a regression coefficient $=0,061$ and $\mathbf{t}_{\text {sig }}=0,524$. Although the Health variable was well perceived by respondents, it had no significant effect on Attitude toward Local Food. This is because every food is perceived to have nutritional content, because the purpose of producing or making a food for consumption is to nourish the body, so either consume Bakso Bakar Trowulan, or other types of food such as Soto, Rawon, Pecel, etc. must also contain health value. Therefore, Health is not a determining factor for respondents in Attitude toward Local Food Bakso Bakar Trowulan. However, according to respondents, the nutritional content of Bakso Bakar Trowulan is considered to be good, but not significant because it feels the same as when customers consume food elsewhere. Either eating at Bakso Bakar Trowulan or elsewhere, customers can still get nutritional content from eating food. Therefore, this factor is not a significant factor in influencing the respondent's decision to Attitude toward Local Food on Trowulan Baked Bakso.

The Epistemic variable is a variable that has negative correlation and does not significantly influence Attitude Toward Local Food at Bakso Bakar Trowulan with a regression coefficient $=-0,074$ and $t_{\text {sig }}=0,411$. Although the epistemic variable has been well perceived by respondents, it has no significant effect on Attitude Toward Local Food. Even though it has an insignificant effect, by consuming Bakso Bakar Trowulan, respondents can be helped in understanding the culinary culture in Malang and the culture of the people of Malang. But getting to understand the culture, the attitude of the respondents towards local food cannot be positive. This is because ethnic groups of Malang people are known for upholding the value of togetherness (www.malangguidance.com, available for download on January 29, 2021). The more respondents understand the culture of Malang people who uphold this togetherness, the more negative the attitude will be to the culinary culture of Malang. This is related to health problems, although culture is a positive thing because it shows closeness / intimacy / warmth among people. But on the other hand, if it is applied in culinary, it means that there is no distance between buyers and sellers, including between one customer and another customer. This kind of culture is also applied to the Bakso Bakar Trowulan Restaurant, where the value of togetherness is shown by the absence of a barrier between sellers and buyers by creating a self-service culinary culture. This selfservice encourages each buyer to freely access the complementary ingredients of the meatballs and mix the food he orders himself, in this case grilled meatballs. This certainly raises concerns, because foodstuffs that are accessed by many people in turn will certainly be vulnerable to the possibility of being contaminated, because the cleanliness and hygiene of each customer cannot be guaranteed. This is also proven in research where the health variable has a positive effect, which shows that respondents also still consider the element of hygiene in culinary. Therefore there is an opposite effect, where customers still assess the value of health which has a positive health effect, but it is not supported by an epistemic which has a culture of togetherness which is feared that it will cause health problems by not guaranteeing the cleanliness and hygiene of customers in ingredients and mixing own ordered food. From this basis, the Epistemic has a negative influence on attitudes towards local food. 
Attitude Toward Local Food on Food Destination Image variables are endogenous variables in this study. Variables that influence Food Destination Image are Attitude Toward Local Food with a regression coefficient $=0,769$ and tsig $=0,000$. This result can be because when customers come to visit to eat Bakso Bakar Trowulan, they evaluate and the result is a sense of pleasure, enthusiasm and feeling positive things. From this basis, it can be a factor that makes customers get an idea that Bakso Bakar Trowulan has the image of Malang's typical grilled meatball food.

Food Destination Image on Repurchase Intention variables are endogenous variables in this study. Variables that influence Repurchase Intention are Food Destination Image with a regression coefficient $=$ 0,766 and tsig $=0,000$. This result can be because when customers come to visit to consume Bakso Bakar Trowulan, consumers get an idea that Bakso Bakar Trowulan has the image of Malang's typical grilled meatball that makes customers feel satisfied, so it can be one of the factors that makes customers loyal and recommends Trowulan Bakso Bakso to other people.

\section{Conclusion}

This study provides evidence that the Quality variable significantly influences Attitude Toward Local Food, the Health variable has no significant effect on Attitude Toward Local Food, the Price variable significantly influences Attitude Toward Local Food, the Emotional variable significantly influences Attitude Toward Local Food, the Prestige variable significantly influences Attitude Toward Local Food, the Interaction variable has no significant effect on Attitude Toward Local Food, the Epistemic variable has no significant effect on Attitude Toward Local Food, the Attitude Toward Local Food variable significantly influences Food Destination Image, and Food Destination Image variable significantly influences Repurchase Intention.

\subsection{Managerial Implications}

Table 5: Managerial Implications

\begin{tabular}{|l|l|}
\hline Current Research & Managerial Implications \\
\hline $\begin{array}{l}\text { Emotional is one of the } \\
\text { elements that is the focus in } \\
\text { the process of increasing } \\
\text { Attitude Toward Local Food. }\end{array}$ & $\begin{array}{l}\text { Maintain good air circulation, because the cool air in Malang is a special } \\
\text { attraction for customers. }\end{array}$ \\
$\begin{array}{l}\text { Collaborating with various services or tourism service providers to be } \\
\text { able to make holiday packages with various natural tourism destinations, } \\
\text { artificial tours and culinary tours with one of the objectives being Bakso } \\
\text { Bakar Trowulan. } \\
\text { Building cooperation with the Department of Culture and Tourism of } \\
\text { Malang City to be able to create a culinary tourism program by visiting } \\
\text { various legendary special food destinations in Malang, with one of the } \\
\text { objectives being Bakso Bakar Trowulan. }\end{array}$ \\
\hline $\begin{array}{l}\text { Prestige is one of the } \\
\text { elements that is the focus in } \\
\text { the process of increasing } \\
\text { Attitude Toward Local Food. }\end{array}$ & $\begin{array}{l}\text { The presentation of Bakso Bakar Trowulan must be better and more } \\
\text { attractive by using a special bowl that is different from other meatball } \\
\text { bowls in general, so that other people can be impressed when customers } \\
\text { show photos / videos of this food. }\end{array}$ \\
$\begin{array}{l}\text { The lighting conditions must be considered, so that the food served can } \\
\text { be seen clearly on the camera when the photos / videos are displayed by } \\
\text { customers to others. } \\
\text { Bakso Bakar Trowulan must be consistent in making unique, delicious } \\
\text { and attractive dishes, so that customers feel worthy to share the } \\
\text { experience of eating this food with others. }\end{array}$
\end{tabular}




\begin{tabular}{|c|c|}
\hline & $\begin{array}{l}\text { - Bakso Bakar Trowulan must maintain its image as a legendary Malang } \\
\text { food with a unique and delicious taste, so that customers can continue to } \\
\text { feel proud of consuming this food. }\end{array}$ \\
\hline $\begin{array}{l}\text { Quality is one of the } \\
\text { elements that is the focus in } \\
\text { the process of increasing } \\
\text { Attitude Toward Local Food }\end{array}$ & $\begin{array}{l}\text { - Cooperate with local cattle breeders to get fresh beef, cooperate with } \\
\text { suppliers of vermicelli, celery leaves and fried onions to get the best } \\
\text { quality ingredients. } \\
\text { - To innovate in making choices for other types of processed meatballs, } \\
\text { such as mushroom meatballs, corn meatballs, and quail egg meatballs, to } \\
\text { increase the uniqueness of the meatballs } \\
\text { - Maintain the right level of doneness during the roasting process of the } \\
\text { meatballs, in order to maintain the consistency of delicious flavors. } \\
\text { - Innovating to create new variations of grilled meatball sauce, such as } \\
\text { mantai sauce, barbecue sauce, teriyaki sauce, etc. in order to add to the } \\
\text { attractiveness of Bakso Bakar. }\end{array}$ \\
\hline $\begin{array}{l}\text { Price is one of the elements } \\
\text { that is the focus in the } \\
\text { process of increasing } \\
\text { Attitude Toward Local Food. }\end{array}$ & $\begin{array}{l}\text { - Selling grilled meatball menu at an affordable price for all people. } \\
\text { - Selling grilled meatballs per unit according to the price of other similar } \\
\text { meatballs in Malang City. } \\
\text { - Maintaining the taste and quality served is always commensurate with } \\
\text { the amount of money spent by the customer. }\end{array}$ \\
\hline $\begin{array}{l}\text { Food Destination Image is } \\
\text { one of the elements that is } \\
\text { the focus in the process of } \\
\text { increasing Repurchase } \\
\text { Intention }\end{array}$ & $\begin{array}{l}\text { - Bakso Bakar Trowulan must continue to make various quality } \\
\text { improvements, customers can feel enthusiasm when consuming this } \\
\text { food. } \\
\text { - Bakso Bakar Trowulan must continue to be committed to providing food } \\
\text { that inspires interest, customers can feel happy when eating this food. } \\
\text { - The employees of Bakso Bakar Trowulan must provide satisfying } \\
\text { service, customers have a positive impression when consuming this } \\
\text { food. }\end{array}$ \\
\hline $\begin{array}{l}\text { Attitude Toward Local Food } \\
\text { is one of the elements that is } \\
\text { the focus in the process of } \\
\text { increasing Food Destination } \\
\text { Image }\end{array}$ & $\begin{array}{l}\text { - Bakso Bakar Trowulan must be promoted as a delicious food in Malang } \\
\text { City. } \\
\text { - Collaborate with artists or influencers, in order to promote the image of } \\
\text { Bakso Bakar Trowulan as a culinary destination that has an image of the } \\
\text { taste of typical poor food. } \\
\text { - Bakso Bakar Trowulan must be promoted as a unique food in Malang } \\
\text { City. } \\
\text { Bakso Bakar Trowulan can participate in culinary festivals organized by } \\
\text { the local government, to educate the culture of culinary diversity in } \\
\text { Malang. }\end{array}$ \\
\hline
\end{tabular}

Based on the characteristics of the respondents in this study, respondents came to Malang with the aim of refreshing natural tourism, artificial tourism, as well as culinary tourism. Then the emotional variable is the variable that has the greatest influence in this study, therefore the main recommendations that must be made for the object of this study are, in collaboration with various services or tourism service providers to be able to make holiday packages with various natural tourist destinations, artificial tourism and a culinary tour with one of the objectives is Bakso Bakar Trowulan. 


\subsection{Recommendation}

- The next subsequent studies can carry out a replication model or be able to make an adjustment model applied to different research objects can obtain more general results about the factors - factors affecting Repurchase Intention, Food Destinations Image and Attitude Toward Local Food.

- further research can complement the various variables contained in this study to further deepen the understanding of the factors that affect Buyback Intention, Food Purpose Image, and Attitudes Toward Local Food.

- Further research is expected to expand the research by selecting respondents outside of the current research. So that further research can provide a broader picture of Repurchase Intention, Food Destination Image and Attitude Toward Local Food.

- In addition, AMOS software with Structured Equation Model (SEM) is expected to be used for further research.

\section{References}

Artuger, S. \& Cetinsoz, B. C. (2017). The impact of destination image and the intention to Revisit: A study Regarding Arab Tourists. European Scientific Journal, 13(5), 82-98.

Ariani, D. W. (2014). Manajemen Kualitas.

Choe, J. Y. J. \& Kim, S. S. (2018). Effects of tourists' local food consumption on attitude, Food Destination Image, and behavioral intention. International Journal of Hospitality Management, 71, 1-10.

Chaplin, J. P. (2011). Kamus Lengkap Psikologi.

Destari, F. (2017). Meningkatkan Intention to Revisit melalui Keunikan Jasa Pariwisata \& Destination Image: Studi Kasus pada Big Event JFC.

Friston, K. Rigoli, F. Ognibene, D. Mathys, C. Fitzgerald, T. \& Pezzulo, G. (2015). Active inference and epistemic . Cognitive neuroscience, 6(4), 187-214.

Gitosudarmo, I. (2014). Manajemen Pemasaran. Yogyakarta: BPFE.

Greco, J. \& De Sa, L. P. (2018). Epistemic.

Jones, K. \& Moital, M. (2017). Techniques employed to create event Prestige for corporate VIPs: the VIP Framework. European Journal of Tourism, Hospitality and Recreation, 8(2), 117-129.

Kotler, P, dan Amstrong, G, Prinsip-prinsip Pemasaran Edisi kedelapan. Jakarta: Erlangga, 2014, 439.

Lifestyle.okezone.com. (2019, 29 October). Kuliner Miliki Peran Penting di Pariwisata Indonesia. Accesses on 29 Mei 2020 , dari https://lifestyle.okezone.com/read/2019/10/29/12/2123037/kuliner-miliki-peran-penting-di-pariwisata-indonesia.

Malang-gudance.com. (2011, 20 March). Kesenian \& Kebudayaan Kota Malang. Accesses on 29 January 2021, dari https://www.malangguidance.com/kesenian-kebudayaan-kota-malang/.

Oetoro, S. Parengkuan, E. \& Parengkuan, J. (2013). Smart Eating: 1000 Jurus makan pintar \& hidup bugar. Jakarta: PT Gramedia Pustaka Utama.

Prayogo, D. \& Suryawan, I. B. (2018). Dampak Fenomena Wisata Kuliner Terhadap Kunjungan Wisatawan di Kota Malang, Jawa Timur. Jurnal Destinasi Pariwisata. 5(2).

Purwianti, L. \& Tio, K. (2017). Faktor-faktor yang mempengaruhi behavioural intention. Jurnal Manajemen Maranatha, 17(1), 15-32.

Romlah, (2010). Psikologi Pendidikan. Malang: Universitas Muhammadiyah Malang.

Riyanto, H. Y. (2014). Paradigma Baru pembelajaran: Sebagai referensi bagi pendidik dalam Implementasi Pembelajaran yang Efektif dan berkualitas. Prenada Media.

Salsabilla, S. (2017). Hubungan Pengetahuan Gizi Dengan Sikap Mengkonsumsi Makanan Sehat Siswa SMK. KELUARGA: Jurnal Ilmiah Pendidikan Kesejahteraan Keluarga, 3(1).

Sheth, J. N. Newman, B. I. \& Gross, B. L. (1991). Why we buy what we buy: A theory of consumption s. Journal of business research, 22(2), 159-170. 
Soebagyo, S. (2012). Strategi pengembangan pariwisata di Indonesia. Liquidity, 1(2), 153-158.

Sudaryono, D. (2016). Manajemen Pemasaran Teori dan Implementasi. Yogyakarta: Andi.

Sunyoto, D. \& Susanti, F. E. (2015). Manajemen Pemasaran Jasa Merencanakan, Mengelola, dan Membidik Pasar Jasa. Yogyakarta: CAPS (Center for Academic Publishing Service).

Susanto, H, 2013; The Miracle of Language. Jakarta: Kompas Gramedia.

Wibowo, A. F. \& Riyadi, E. S. H. (2017). Pengaruh Gaya Hidup, Prestise dan Kelompok Referensi Terhadap Keputusan Pembelian (Studi pada Pelanggan Taiwan Tea House Semarang).

\section{Appendix}

Table 6: The Items List Used in the study

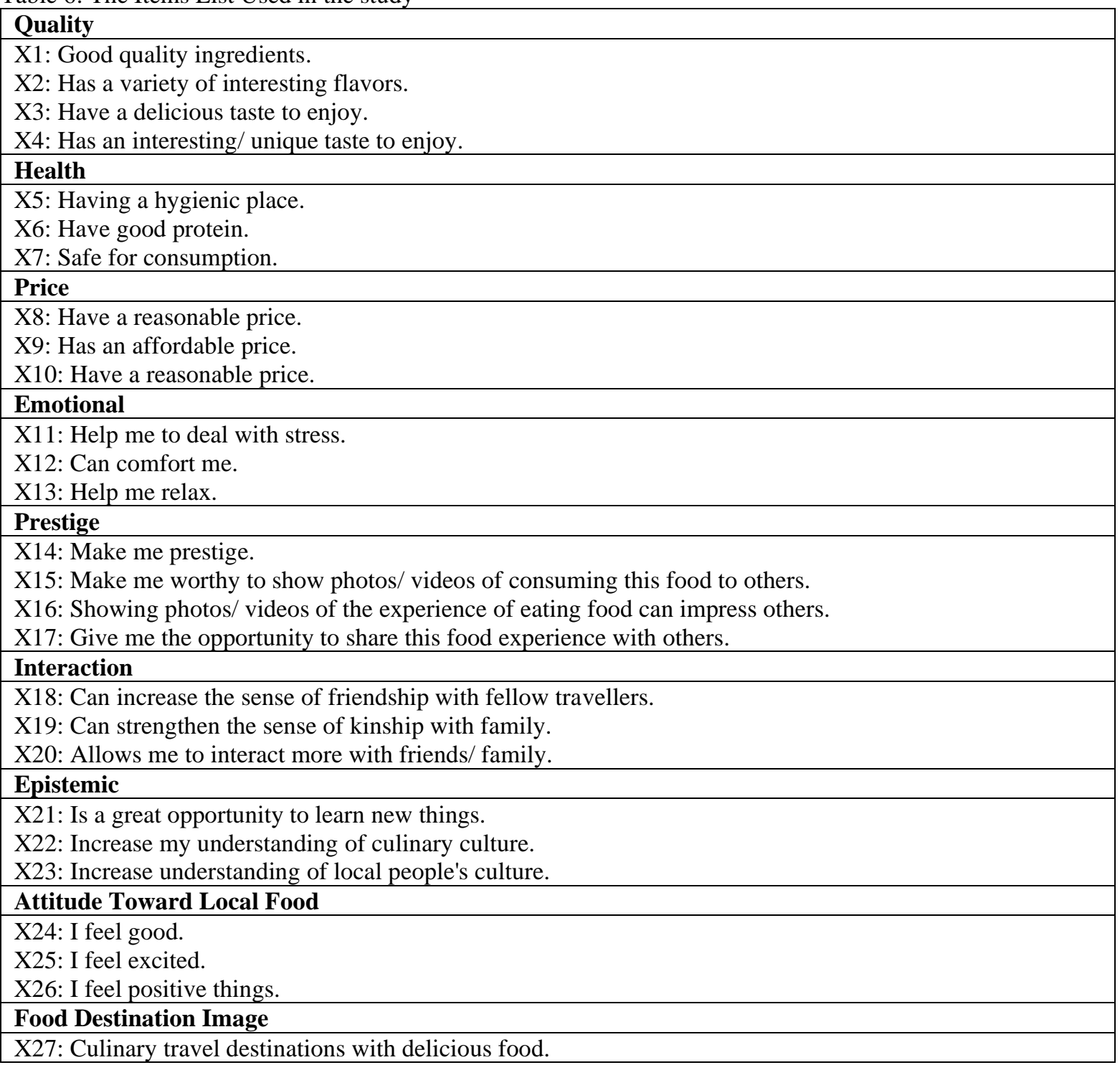


X28: Culinary tourism destinations that provide unique foods.

X29: Culinary tourism destinations that provide food that has a distinctive taste image.

$\mathrm{X} 30$ : Culinary tourism destinations with foods that are rich in culture.

\section{Repurchase Intention}

X31: I will say positively about this delicious food to others.

$\mathrm{X} 32$ : I would recommend this meal to family or friends.

$\mathrm{X} 33$ : I want to come back to enjoy this meal. 